\title{
Differences in anti-inflammatory actions of intravenous immunoglobulin between mice and men: more than meets the eye
}

\author{
Angela S. W. Tjon ${ }^{1 \dagger}$, Rogier van Gent ${ }^{1 \dagger}$, Teunis B. Geijtenbeek ${ }^{2}$ and Jaap Kwekkeboom ${ }^{1 *}$ \\ ${ }^{1}$ Department of Gastroenterology and Hepatology, Erasmus MC-University Medical Center, Rotterdam, \\ Netherlands, ${ }^{2}$ Department of Experimental Immunology, Academic Medical Center, Amsterdam, Netherlands
}

\section{OPEN ACCESS}

Edited by:

Marc H. V. Van Regenmortel,

University of Strasbourg, France

Reviewed by:

Luuk Hilbrands,

Radboud University Nijmegen Medical

Centre, Netherlands

Dominic Paquin Proulx,

George Washington University, USA

*Correspondence:

Jaap Kwekkeboom,

Department of Gastroenterology and Hepatology, Erasmus MC-University

Medical Center, Room Na-1009,

Rotterdam 3015 CE, Netherlands

j.kwekkeboom@erasmusmc.nl

${ }^{\dagger}$ Angela S. W. Tjon and

Rogier van Gent have contributed equally to this work.

Specialty section:

This article was submitted to Immunotherapies and Vaccines, a section of the journal Frontiers in

Immunology

Received: 12 February 2015 Accepted: 09 April 2015

Published: 28 April 2015

Citation:

Tjon ASW, van Gent $R$ Geijtenbeek TB and Kwekkeboom $J$

(2015) Differences in

anti-inflammatory actions of intravenous immunoglobulin between mice and men: more than meets

the eye.

Front. Immunol. 6:197. doi: 10.3389/fimmu.2015.00197
Intravenous immunoglobulin (IVIg) is a therapeutic preparation of polyspecific human IgGs purified from plasma pooled from thousands of individuals. When administered at a high dose, IVIg inhibits inflammation and has proven efficacy in the treatment of various autoimmune and systemic inflammatory diseases. Importantly, IVlg therapy can ameliorate both auto-antibody-mediated and T-cell mediated immune pathologies. In the last few decades, extensive research in murine disease models has resulted in the elucidation of two novel anti-inflammatory mechanisms-of-action of IVlg: induction of FcyRIIB expression by sialylated Fc, and stimulation of regulatory $T$ cells. Whereas controversial findings in mice studies have recently inspired intense scientific debate regarding the validity of the sialylated Fc-Fc $\gamma R$ RIIB model, the most fundamental question is whether these anti-inflammatory mechanisms of IVIg are operational in humans treated with IVIg. In this review, we examine the evidence for the involvement of these antiinflammatory mechanisms in the therapeutic effects of IVIg in humans. We demonstrate that although several elements of both immune-modulatory pathways of IVIg are activated in humans, incorrect extrapolations from mice to men have been made on the molecular and cellular components involved in these cascades that warrant for critical re-evaluation of these anti-inflammatory mechanisms of IVIg in humans.

Keywords: IVIg, anti-inflammatory, autoimmunity, sialylation, regulatory T cells, Fc $\gamma$ receptors

\section{Introduction}

Intravenous immunoglobulin (IVIg) was initially administered to restore humoral immunity in patients with primary or secondary immunodeficiency, as it contains a wide spectrum of antibody specificities, representative for the natural antibody repertoire of the adult human population. After it had been shown that high-dose IVIg treatment (fourfold higher than supplementation dose) (1) could ameliorate idiopathic thrombocytopenic purpura (ITP) (2), its anti-inflammatory properties have increasingly been exploited to treat various autoimmune and systemic inflammatory diseases.

Several non-exclusive mechanisms by which IVIg exerts its anti-inflammatory effects have been elucidated over the past few decades. These include neutralization of autoantibodies by anti-idiotype interactions, increased clearance of pathogenic antibodies by saturation of the neonatal $\mathrm{FcR}(\mathrm{FcRn})$, prevention of binding of pathogenic immune complexes (ICs) to activating Fc $\gamma$-receptors (Fc $\gamma \mathrm{R}$ ), modulation of Fc $\gamma \mathrm{R}$ expression, inhibition of the complement cascade, reduced pro-inflammatory 
cytokine production, inhibition of dendritic cells (DCs) and B cells, inhibition of T-helper (Th) 1 and Th17 differentiation, and expansion and enhanced suppressive function of $\mathrm{CD}^{+}{ }^{+} \mathrm{FOXP} 3^{+}$ regulatory $\mathrm{T}$ cells (Tregs) $(1,3-7)$.

It is important to realize that most of the anti-inflammatory mechanisms of IVIg have been elucidated in murine studies. Of course, studies using animal models are ideal to determine causal relationships between the elements of anti-inflammatory cascades. However, it is actually surprising that validation of these mechanistic findings in human patients treated with IVIg is severely lacking. Extrapolation of the anti-inflammatory mechanisms from murine studies to humans treated with IVIg is by no means trivial as fundamental differences between the murine and human immune system, as well as the xenobiotic nature of human IgGs when administered to a different organism, are likely to affect the mode-of-action of IVIg within these species.

In this review, we investigate the similarities and differences between the anti-inflammatory mechanisms activated by IVIg in mice and humans. We will focus on the two most advertised antiinflammatory mechanisms in recent years: induction of Fc $\gamma$ RIIB expression by sialylated Fc and stimulation of Tregs. We examine the evidence for the involvement of their proposed cellular and molecular components in immunomodulation by IVIg therapy in humans and, when validation in humans is still lacking or incomplete, discuss their translatability from murine to human studies by taking the biology of both species into account.

\section{Sialylated IVIg and Fc $\gamma$ RIIB Upregulation}

In the last decade, landmark studies have revealed that IgGs with $\alpha 2,6$-sialic acid-containing $\mathrm{N}$-linked glycans attached to the IgG $\mathrm{Fc}(\mathrm{sFc})$ display potent anti-inflammatory activity in antibodymediated inflammation in experimental animal models. Identification of the anti-inflammatory properties of this IgG fraction started with a study in a murine ITP-model in which the protective effects of IVIg appeared dependent on (1) upregulation of Fc $\gamma$ RIIB expression on effector macrophages, thereby limiting IC-mediated activation, and (2) the IgG Fc (8). In subsequent studies, the protective effect of IVIg in a mouse model of ICmediated $(\mathrm{K} / \mathrm{BxN})$ arthritis was shown to be mediated by colony stimulating factor-1 (CSF-1)-dependent macrophages that act as sensors for IVIg and are involved in the induction of inhibitory Fc $\gamma$ RIIB expression on CSF-1-independent effector macrophages, thereby raising the threshold for activation of these cells by auto-antibody-IC (9). These CSF-1-dependent IVIg-sensoring macrophages were identified as splenic SIGN-R1 ${ }^{+}$marginal zone macrophages (MZM) which were able to bind $\mathrm{sFc}(10)$.

Parallel studies demonstrated that $\mathrm{sFc}$ was essential for the antiinflammatory activity of IVIg in the $\mathrm{K} / \mathrm{BxN}$ arthritis model in a Fc $\gamma$ RIIB-dependent manner (11-13). Infusion of sFc protected wild type, but not SIGN-R1 ${ }^{-1-}$ mice from arthritis, suggesting that binding of $s F c$ to SIGN-R1 on MZM was required for the anti-inflammatory effect (10). A human ortholog of SIGN-R1, DC-SIGN, was also able to bind sFc ex vivo (10), and the protective activity of $s F c$ and sialylated IVIg (sIVIg) was retained upon induction of arthritis in SIGN-R1 $1^{-1-}$ mice that transgenically expressed human DC-SIGN (13). These data suggested that
DC-SIGN might be able to mediate the anti-inflammatory properties of sIVIg in humans in vivo. In addition, it was shown that sIVIg induced the production of IL-33 in the spleen of wild type but not SIGN-R1 ${ }^{-1-}$ mice. IL-33 subsequently promoted expansion of basophils in the circulation and stimulated their production of IL4 and IL-13, which enhanced the expression of Fc $\gamma$ RIIB expression on macrophages and monocytes, thereby providing a link between IVIg-sensor macrophages and induction of Fc $\gamma$ RIIB expression on myeloid effector cells (Figure 1) (13).

The elucidation of this mechanistic model, that is founded on the absolute requirement of $\mathrm{sFc}$ and $\mathrm{Fc} \gamma \mathrm{RIIB}$ expression, seemed to profoundly improve our understanding of the protective effects of IVIg in antibody-mediated inflammation in mice. However, due to findings in other murine studies on IVIg, intense scientific debate regarding the validity of this anti-inflammatory model has commenced. Upregulation of inhibitory Fc $\gamma$ RIIB expression by IVIg has been demonstrated in various animal models as an effector mechanism by which antibody-mediated immune diseases are prevented $(8,9,14)$. In contrast, in murine studies on $\operatorname{ITP}(15,16)$ and experimental autoimmune encephalomyelitis (EAE) (17), the beneficial effect of IVIg was also observed in $\mathrm{Fc}_{\mathrm{RIIB}}{ }^{-1-}$ mice, challenging the absolute requirement for FcyRIIB in IVIg-treated mice. In addition, various recent reports question whether Fcsialylation is absolutely required for the anti-inflammatory effects of IVIg in mice (18). In several studies on murine models of $\operatorname{ITP}(19,20)$ [in contrast to other studies on ITP reporting an indispensable role for sialylation $(11,14,21)]$, EAE (22), arthritis (23), and herpes simplex virus (HSV)-induced encephalitis (24), the anti-inflammatory properties of IVIg were sialylationindependent. In addition, the contribution of the IgG Fc-part to the anti-inflammatory effects of IVIg has been questioned in a study showing that the protective effects of IVIg in a mouse EAE model were $\mathrm{F}\left(\mathrm{ab}^{\prime}\right)_{2}$-dependent (17).

A matter that may complicate this debate is that in most murine studies IVIg was administered prophylactically, while in humans IVIg is given after a disease has established. This difference complicates translation of insights from murine studies to humans. A recent comparison between prophylactic and therapeutic IVIg treatments in several murine disease models (ITP, arthritis and skin-blistering disease) has shown that the anti-inflammatory effects of IVIg were similar, and were dependent on FcyRIIB expression and sialylation, although SIGN-R1 was not essential in all disease models when IVIg was administered therapeutically (14). These data suggest that there is considerable overlap between the anti-inflammatory activities of IVIg in mice upon prophylactic or therapeutic administration, but it would be helpful if future murine studies concentrated on the anti-inflammatory activities of therapeutic IVIg administration only.

A recent study by Washburn et al. reported that some of the discrepancies between studies on sIVIg or sialylated Fc may be caused by differences in the protocols used to generate and/or purify sialylated or desialylated IVIg/Fc. Commonly used sialyltransferase enzyme preparations were found be contaminated with other glycolytic enzymes that catalyzed undesired modifications in the enzymatically produced sialylated IgG/Fc products. By establishing industrial-scale protocols and quality control steps, Washburn et al. enzymatically generated tetra Fc-sialylated IVIg 


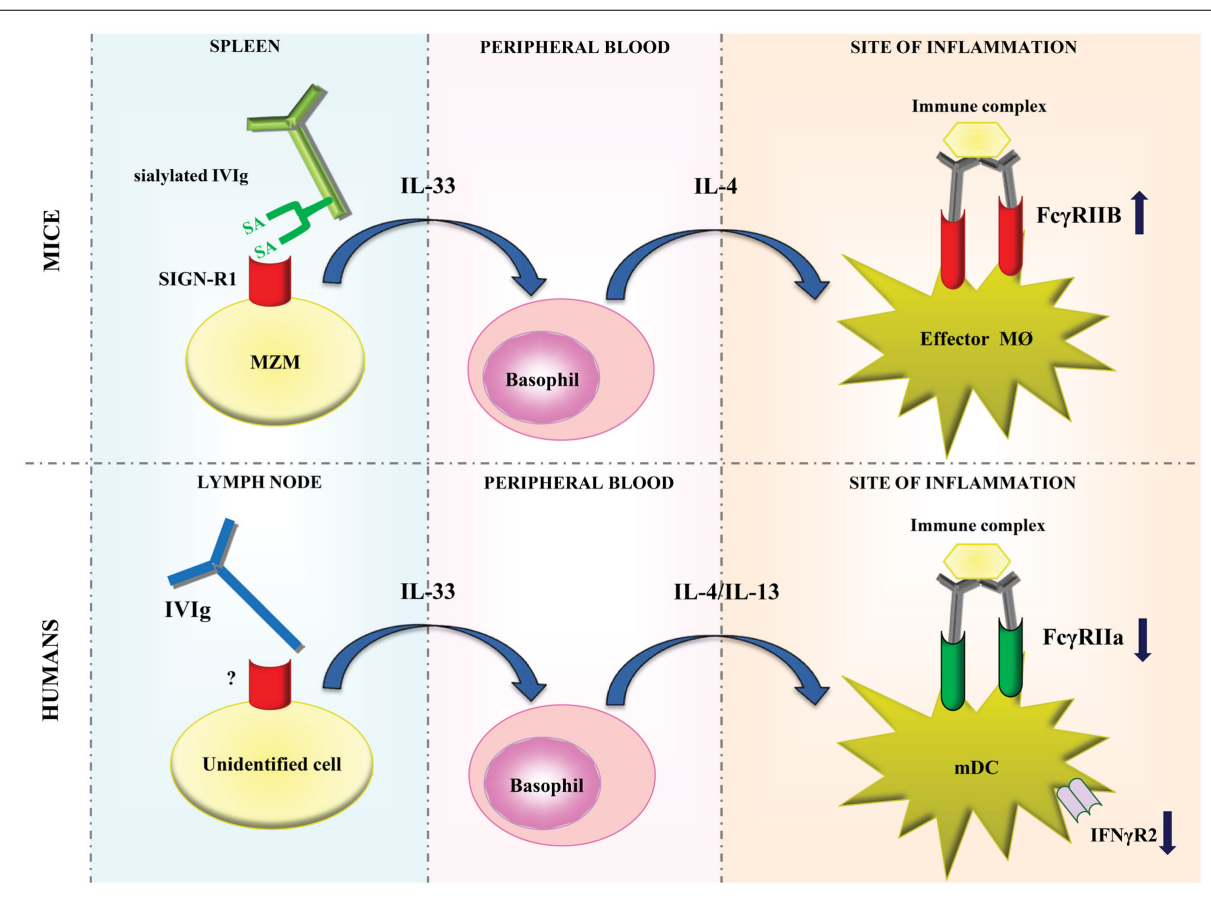

FIGURE 1 | Models of modulation of Fc $\gamma R$ expression by IVIg in mice and humans. In mice, sialylated IVIg is hypothesized to bind to SIGN-R1 expressed on splenic marginal zone macrophages and induce IL-33 production. IL-33 subsequently promotes the production of IL-4 by basophils, which enhances the expression of FcyRIIB expression on effector macrophages at the site of inflammation. In humans, IVIg may bind to an, as of yet, unidentified cell type which probably resides in lymph nodes. This is hypothesized to induce IL-33 production, which in turn enhances IL-4 and IL-13 production by basophils resulting in decreased expression of Fc $\gamma R$ Rlla and IFN $\gamma R 2$ on myeloid dendritic cells. MZM, marginal zone macrophages; SA, sialic acid; $M \varnothing$, macrophage; $\mathrm{mDC}$, myeloid dendritic cell.
(s4-IVIg; the glycans on each of the two heavy chains terminate in two sialic acid residues) that was devoid of undesired modifications in the glycan structures. When administered in four different murine disease models, s4-IVIg was as effective as conventional IVIg, but at a 10-fold lower dose. This was apparent when s4-IVIg was given prophylactically as well as therapeutically. It has to be noted though that therapeutic and prophylactic IVIg treatments were not compared in the same disease model (25). In addition, this study does not refute the data from other published studies in which treatment with desialylated IVIg was still as effective as treatment with conventional IVIg $(22,23)$.

Regardless of these contradictory findings, the most fundamental question now is whether there is any evidence that a similar mechanism mediates the anti-inflammatory effects of high-dose IVIg-therapy in humans. In the following sections, we will show in a balanced account that there is indeed evidence, although limited and circumstantial, for activation of this anti-inflammatory pathway by IVIg in humans. However, due to biological differences between mice and men, a number of issues regarding the anti-inflammatory actions of IVIg in humans, such as involvement of Fc $\gamma$ RIIb modulation, splenic MZM, DC-SIGN, and the dependence on $\mathrm{sFc}$, need to be critically reconsidered.

\section{IVIg and Fc $\gamma$ Illb Expression in Humans}

Is there any evidence for the increase of Fc $\gamma$ RIIb expression in humans treated with IVIg? Recently, we found no increase of FcyRIIb expression on circulating monocytes and DCs in patients treated with high-dose IVIg for diverse autoimmune pathologies (26). These data corroborate findings in IVIg-treated patients with common variable immunodeficiency (CVID) which showed that $F c \gamma R I I b$ mRNA expression of circulating monocytes did not change upon low-dose IVIg treatment (27). Two other studies on patients with ITP and Kawasaki disease also showed no upregulation of FcyRIIb expression on monocytes after IVIg infusion, however, the validity of these results can be questioned as the antibody used to detect Fc $\gamma$ RIIb in these studies binds to an intracellular epitope of the protein while no permeabilization protocol was applied $(28,29)$. In in vitro studies, IVIg did not induce upregulation of Fc $\gamma$ RIIb expression on human myeloid DCs $(26,30)$. These findings seemed to be corroborated in a recent study that showed no modulation of FcyRIIb expression by IVIg on human macrophages in vitro. However, in this study IVIg was added to the cultures at a concentration at least 100-fold lower than the concentration required to reflect the increment in IgG levels observed upon high-dose IVIg treatment in vivo $(10 \mathrm{mg} / \mathrm{ml})$ (31). In contrast to these studies, a majority of patients with chronic inflammatory demyelinating polyneuropathy (CIDP) showed increased expression of Fc $\gamma$ RIIb on monocytes and B cells after IVIg treatment (32). It has to be noted that the untreated CIDP patients in this study showed reduced Fc $\gamma$ RIIb expression and the observed increase may have reflected a normalization of Fc $\gamma$ RIIb expression levels upon reduction of overall inflammation by IVIg therapy. So strikingly, whereas IVIg treatment in several murine studies has shown to stimulate expression of inhibitory Fc $\gamma$ RIIB on myeloid 
cells $(8,9,24)$, most evidence in humans shows that FcyRIIb expression is not affected by IVIg, although these findings need to be extended in independent studies without technical issues.

Do these observations therefore imply that modulation of Fc $\gamma \mathrm{R}$ expression is not involved in the anti-inflammatory effects of IVIg treatment in humans? Although we did not find increase of Fc $\gamma$ RIIb expression after high-dose IVIg treatment in patients with autoimmune diseases, we did find downregulation of another Fc $\gamma R$, the activating Fc $\gamma$ RIIa, on circulating myeloid DCs (26). Given the differences in expression of Fc $\gamma$ Rs between mice and men, it is not surprising that the effects of IVIg treatment on $\mathrm{Fc} \gamma \mathrm{R}$ modulation in mice are distinct from those in humans. Humans have six different Fc $\gamma$ Rs, namely Fc $\gamma$ RIa, Fc $\gamma$ RIIa, Fc $\gamma$ RIIb, Fc $\gamma$ RIIc, Fc $\gamma$ RIIIa, and Fc $\gamma$ RIIIb, while mice have four: Fc $\gamma$ RI, Fc $\gamma$ RIIB, Fc $\gamma$ RIII, and Fc $\gamma$ RIV (33-35). Thus, Fc $\gamma$ RIIa, which we showed to be downregulated by IVIg treatment, is not present in mice.

In addition to downregulation of Fc $\gamma$ RIIa expression on circulating myeloid DCs, we observed an increase in plasma levels of IL-33 and the Th2 cytokines IL-4 and IL-13 upon high-dose IVIg treatment, showing homology between the anti-inflammatory activity of IVIg in mice and men (26). Enhanced IL-33 plasma levels were also observed in another study in a cohort of autoimmune disease patients treated with IVIg, although IL-4 in plasma of these patients was hardly detectable and no expansion of basophils in peripheral blood of these patients was observed (36). In vitro experiments on human myeloid DCs suggested that Fc $\gamma$ RIIa downregulation after IVIg treatment is not directly caused by IVIg, but rather indirectly by the elevated levels of IL- 4 and IL-13, and resulted in suppressed responses of myeloid DCs to IC-stimulation (26).

Thus, IVIg therapy downregulates expression of the activating FcyRIIa in humans, instead of upregulation of the inhibitory Fc $\gamma$ RIIB as was observed in mice (Figure 1). Interestingly, we found that activation of the cytokine cascade involving IL-33 and the Th2 cytokines IL- 4 and IL-13 by IVIg is shared by mice and men. In addition, we found that these cytokines also downregulate expression of the IFN- $\gamma$ receptor 2 subunit on myeloid DCs in humans (26), which may contribute to suppression of cellular immunity by IVIg (Figure 1) (37).

In a study by Siragam et al., it was shown that IVIg could also confer its anti-inflammatory effects by affecting signaling through activating Fc $\gamma$ Rs. In a mouse model of ITP, IVIg ameliorated the disease by directly interacting with activating Fc $\gamma$ Rs, but not the inhibitory Fc $\gamma$ RIIB, on DCs. Strikingly, adoptive transfer of ex vivo IVIg-treated DCs was able to ameliorate ITP. These data suggest that IVIg forms soluble ICs in vivo that prime dendriticcell regulatory activity (38). This may be not entirely surprising as it is likely that the infused IgGs are able to bind to xenogeneic polymorphic murine proteins, resulting in the formation of soluble ICs. Although intriguing, there is to date no evidence that a similar mechanism of action of IVIg occurs in humans.

\section{IVlg-Sensing Cell Types in Human Lymphoid Organs}

Since high-dose IVIg induces the production of IL-33 and Th2 cytokines IL- 4 and IL-13 in humans, the question emerges by which cell types these cytokines are produced. It is likely that, as in mice, basophils are the cellular source of IL-4 and IL-13 production after IVIg treatment in humans. Several in vitro studies have shown that human basophils produce IL-4 and IL-13 upon stimulation with IL-33 (39-41). The cellular source responsible for IL-33 production upon IVIg treatment however differs between mice and men. In murine studies, it has been demonstrated that splenic MZM are important in initiating the IL-33-Th2 cytokine cascade upon IVIg administration, as the protective effect of IVIg was lost after splenectomy or specific depletion of MZM. Therefore, MZM were suggested to be responsible for binding and initiating the protection mediated by sIVIg or sFc via SIGN-R1 (9, 10). It is important to note though, that it has not yet been formally proven that MZM are the source of IL-33 production upon IVIg treatment in mice. Importantly, the human and murine spleen differ to a major extent, both in morphology and the presence of specific cell types. MZM are diffusely spread within the marginal zone of the murine spleen (42), but they are not present in the human spleen (43). In comparison to the murine spleen, the human spleen contains an additional zone, called the perifollicular zone, which is located between the marginal zone and the red pulp (44). It contains a special subset of macrophages, of which some express DC-SIGN (45). Although their anatomical location in the human spleen is different, it can be speculated that these perifollicular macrophages are the human counterparts of murine MZM and can produce IL-33 upon IVIg treatment.

However, arguing against an indispensable role for the spleen in mediating the anti-inflammatory effects of IVIg in humans is the observation that IVIg is still an effective anti-inflammatory treatment for splenectomized ITP patients (46). This observation suggests that in humans either IL-33 production is dispensible for the anti-inflammatory effect of IVIg therapy or cell type(s) outside the spleen can produce IL-33 upon IVIg treatment. Indeed, IVIg induces $I L-33$ mRNA expression in primary human lymph node cells in vitro (26) but not in human splenocytes $(26,36)$. In human lymph nodes, medullary sinus macrophages (MSM) as well as subcapsular sinus macrophages (SSM) are likely candidates for IVIg-induced IL-33 production in vivo as they express DC-SIGN $(47,48)$. Although we were not yet able to determine whether MSM an SSM are the cellular sources of IL-33, we did establish that human macrophages produce IL-33 upon IVIg exposure in vitro (26). Epithelial cells and fibroblasts can also produce IL-33 and may be alternative cellular sources $(49,50)$.

Recent studies using two different murine models of ITP showed that splenectomy in mice did not impair the protective effect of IVIg $(15,21)$. In one of these models, the protective effect of IVIg was even independent of IL-33 and IL-4 signaling, although still dependent on SIGN-R1 and sFc (21). This suggests that, as in humans, cells at anatomical locations outside the spleen may alternatively mediate the anti-inflammatory properties of sIVIg in mice.

Collectively, these data indicate the need to study which human tissues and cells are involved in stimulation of IL-33 production by IVIg. Obviously, availability of tissues from IVIg-treated patients is limited, but in vitro studies using human tissues and cells can help to clarify which human cell types are able to bind IVIg and produce IL-33. 


\section{Involvement of DC-SIGN in the Anti-Inflammatory Activity of IVIg in Humans}

The evidence that DC-SIGN might be involved in the antiinflammatory response to IVIg in humans is derived from the observation that DC-SIGN can replace its murine ortholog SIGNR1 in IL-33-mediated protection from serum-induced arthritis in mice upon $\mathrm{sFc}$ treatment (13). However, in vitro studies using human DC-SIGN expressing cells did not provide a clear indication for involvement of DC-SIGN in the protective effects of IVIg. We found that induction of IL-33 production in human macrophages by IVIg was not inhibited by blocking DC-SIGN (26). Moreover, human splenocytes and monocyte-derived DCs (moDCs), that both abundantly express DC-SIGN, did not produce IL-33 upon exposure to IVIg $(26,36)$. Currently, the only study showing a role for DC-SIGN in mediating an immunemodulatory effect of IVIg on human cells comes from an in vitro study in which it was shown that DC-SIGN was partially responsible for the IVIg-mediated induction of Tregs by prostaglandin E2 (PGE2)-producing moDCs. However, this effect was not Fc- but $\mathrm{F}\left(\mathrm{ab}^{\prime}\right)_{2}$-dependent and therefore not mediated by $\mathrm{sFc}$ binding to DC-SIGN (51).

Whether DC-SIGN is the proper human homolog of SIGNR1 may be argued. L-SIGN, another human C-type lectin, also shares homology to SIGN-R1 with regard to cellular expression pattern. SIGN-R1 and L-SIGN are both expressed by liver sinusoidal and lymph node endothelial cells (52-54). Scattered cells expressing L-SIGN were also observed in the human splenic perifollicular zone which, as suggested above, might represent the human counterparts to splenic SIGN-R1 ${ }^{+}$MZM in mice (13). Shared human DC-SIGN and murine SIGN-R1 expression has been observed for MSM in lymph nodes $(42,48)$ and, likely similar to L-SIGN, on some macrophages in the perifollicular zone of the human spleen (45). However, DC-SIGN is also expressed on subsets of human monocytes (13), myeloid DCs (53), and SSM in human lymph nodes $(47,48)$, which are cell types in mice that do not express SIGN-R1. L-SIGN is able to bind to sFc in vitro, although with reduced affinity compared to DC-SIGN, which suggests a possible role of L-SIGN in sensing sIVIg in humans. In our opinion, the published results of selective blockade of DC-SIGN in SIGN-R1 $1^{-l-}$ mice that express a human transgene containing both DC-SIGN and L-SIGN, do not completely exclude involvement of L-SIGN in the anti-inflammatory effects of $\mathrm{sFc}$ (13). Additional studies using human cells are required to demonstrate whether L-SIGN and/or DC-SIGN are involved in mediating anti-inflammatory effects of IVIg in humans.

Whether DC-SIGN can bind sIVIg or sFc with sufficient affinity is still a matter of debate. It does not bind sialylated glycans or glycoconjugates (55-57), suggesting that binding of sFc by this lectin must involve non-canonical interactions. A recent study suggested that sialylation of the N-linked Fc glycan structurally affects the IgG C $\gamma 2$ domain, causing a so-called "closed" state of sFc which would enable interaction with DC-SIGN, while asialylated Fc has an "open" state, resulting in preferential binding to Fc $\gamma$ Rs (58). However, this model of sFc-DC-SIGN interaction is controversial and has initiated an ongoing scientific debate as contradictory evidence shows that Fc sialylation does not induce alterations in the Fc conformation $(59,60)$. Moreover, binding affinity of engineered IgG glycoforms that were either hyper$\alpha 2,6$-sialylated, asialylated or deglycosylated to tetramerized DCSIGN was shown not to differ and, strikingly, was Fab- but not Fc-dependent (61).

Taken together, the evidence for a prominent role of DC-SIGN in mediating the anti-inflammatory activity of IVIg in humans is very limited. Moreover, when considering recent murine studies on IVIg, it was shown that SIGN-R1 was dispensable for therapeutic amelioration of ITP as well as prevention of antigen-driven airway disease in mice upon treatment with IVIg $(14,62)$, thereby questioning whether SIGN-R1 is absolutely required to confer the anti-inflammatory properties of IVIg in mice. As we will discuss in the following section, the requirement for $\mathrm{sFc}$ which was found to confer the anti-inflammatory activity of IVIg via DC-SIGN, is even more heavily debated.

\section{Contribution of Fc Sialylation to the Anti-Inflammatory Activity of IVIg in Humans}

The only data available on the contribution of sIVIg to the antiinflammatory effects of IVIg on human immune cells are from a study showing that sIVIg, but not asialyated IVIg, stimulated apoptosis in human B cells in vitro via CD22 (see also Alternative IVIg-Sensing Molecules) (63). However, it seems unlikely that these immunomodulatory effects were mediated by $\mathrm{sFc}$, as in this study sIVIg was enriched by Sambucus nigra agglutinin (SNA) lectin fractionation which mainly enriches $\mathrm{F}\left(\mathrm{ab}^{\prime}\right)_{2}$-sialylated IgG $(20,64)$. Interestingly, infusion of $\mathrm{Fc}$ fragments for treatment of childhood ITP was effective, suggesting that the IgG Fc is involved in the anti-inflammatory effects of IVIg in humans $(65,66)$. However, inhibition of human monocyte function by IVIg was $\mathrm{F}\left(\mathrm{ab}^{\prime}\right)_{2}$-dependent (64). In addition, $\mathrm{F}\left(\mathrm{ab}^{\prime}\right)_{2}$ fragments, but not $\mathrm{Fc}$ fragments, were shown to mediate Treg expansion via human moDC (51).

As previously mentioned, these often paradoxical results have led to an ongoing scientific debate on the importance of Fcsialylation and IgG Fc in the anti-inflammatory activity of IVIg (3). Currently, there is no data showing that specific IgG glycoforms are required for the beneficial effects of IVIg in humans. Studies in which the effects of sIVIg and sFc on human immune cells are compared to those of non-sialylated IVIg and nonsialylated Fc are therefore highly required.

\section{Alternative IVIg-Sensing Molecules}

Despite the contradictory findings on the requirement of Fc sialylation, there are reports that do show a role for sIVIg in relation to two other sialic acid-binding proteins, namely the C-type lectin dendritic cell immunoreceptor (DCIR) and the sialic acid-binding Ig-like lectin (Siglec) CD22. Murine DCIR was shown to specifically bind sIVIg in vitro, and DCIR-expressing tolerogenic DCsinduced expansion of Tregs which attenuated ovalbumin-induced airway hyperresponsiveness in mice in a Fc $\gamma$ R- and SIGN-R1independent manner. Moreover, IVIg-induced DCIR expression on DCs, thereby propagating its anti-inflammatory activity (62). Due to its recent discovery, it has not been explored yet whether DCIR is involved in the anti-inflammatory effects of IVIg in humans. 




$N$-acetyl neuraminic acid (Neu5Ac)

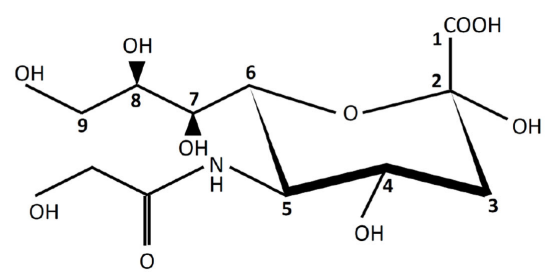

$N$-glycolyl neuraminic acid (Neu5Gc)

\begin{tabular}{ccc} 
& \multicolumn{2}{c}{ synthesized in } \\
\cline { 2 - 3 } humans & mice \\
\hline \hline Neu5Ac & yes & yes \\
Neu5Gc & no & yes \\
\hline
\end{tabular}

\begin{tabular}{ccc} 
& \multicolumn{2}{c}{ binds CD22 in } \\
\cline { 2 - 3 } humans & mice \\
\hline \hline Neu5Ac & yes & no \\
Neu5Gc & yes & yes \\
\hline
\end{tabular}

FIGURE 2 | Sialic acids and binding to CD22. (A) A schematic view of $N$-acetylated and $N$-glycolylated sialic acid structures. The carbon at position 5 is either $\mathrm{N}$-acetylated (left) or $\mathrm{N}$-glycolylated (right). (B) Biosynthesis of sialic acids in humans and mice and binding properties of sialic acids to human or murine CD22.

CD22 (Siglec-2) is expressed on murine and human B cells and murine DCs (67), and binds $\alpha 2,6$-sialic acid-containing glycans with high specificity (68). sIVIg, but not asialyated IVIg, was shown to bind to CD22 on human B cells in vitro, resulting in reduced BCR signaling and enhanced apoptosis upon stimulation with anti-IgM (63).

Arguing against a role for CD22 in mediating the antiinflammatory effects of IVIg is the observation that CD22 $2^{-1-}$ mice were still protected from ITP and serum-induced arthritis by IVIg (69). However, it should be noted that murine studies on the involvement of CD22 in the effects of sIVIg are not valid due to differences between sialic acids in humans and mice. Sialic acids are nine-carbon sugars which contain a carbon ring (C2-C6) and an exocyclic side chain (C7-C9). One group of sialic acids, called neuraminic acids, are $\mathrm{N}$-acetylated at $\mathrm{C} 5$ in the carbon ring, yielding $N$-acetyl neuraminic acid (Neu5Ac) (Figure 2A). In many vertebrates, including mice, this $N$-acetyl group can be converted by the enzyme CMP- $N$-acetyl hydroxylase (CMAH) to a $N$-glycolyl group resulting in $N$-glycolyl neuraminic acid (Neu5Gc). Importantly, CMAH is non-functional in humans (70). Therefore, terminal sialic acids attached to $\mathrm{N}$-linked glycans like those in human IgG molecules are Neu5Ac and not Neu5Gc. While human CD22 binds both Neu5Ac and Neu5Gc, murine CD22 can only bind Neu5Gc ligands (Figure 2B) (71). Therefore, it can be expected that sIVIg cannot bind to murine CD22, and on basis of murine experiments it can therefore not be ruled out that sIVIg modulates immune responses in humans via binding to CD22.

In summary, while a role for DC-SIGN seems unlikely, other sialic acid-binding proteins have been identified that may alternatively mediate the anti-inflammatory properties of sIVIg, but currently there is only some functional evidence for involvement of CD22 in immunomodulation by sIVIg in humans. The fact that IL-33 and Th2 cytokines are elevated in plasma from IVIgtreated patients suggests that there is substantial overlap between the anti-inflammatory activity of IVIg in mice and men, but the molecular mechanism and the cellular source of stimulation of IL-33 production by IVIg needs further investigation.

\section{Stimulation of Regulatory T Cells by IVIg}

Evidence has been accumulating that IVIg exerts its antiinflammatory effects in experimental mice models also by stimulating expansion and suppressive function of $\mathrm{CD} 4^{+} \mathrm{Foxp}^{+}$Tregs. Studies in disease models of ITP $(72), \operatorname{EAE}(17,22,73)$, antigendriven allergic airway disease $(62,74,75)$, Parkinson's Disease (76), HSV-1-induced encephalitis (24), and allogeneic skin transplantation (77) have shown an indispensable role for Tregs in mediating the protective effects of IVIg treatment. Expansion of Tregs upon IVIg treatment was not an epiphenomenon associated with the dampening of an inflammatory reaction, as IVIg did not confer protection in studies in which Tregs were depleted prior to treatment $(73,77)$. A similar expansion of Tregs was observed in humans who were treated with IVIg for various diseases, such as Kawasaki disease $(78,79)$, Guillain Barré Syndrome $(80,81)$, rheumatoid arthritis (82) and eosinophilic granulomatosis with polyangiitis (83). In contrast, no expansion of Tregs was observed in a study on CVID patients that were treated with low-dose IVIg and had reduced Treg levels prior to treatment (84). Similar reduced Treg levels were found in another study on CVID patients after IVIg treatment, although levels of Tregs were not determined prior to treatment in these patients (85). We demonstrated that circulating Tregs in patients with various autoimmune diseases or immunodeficiencies are selectively activated upon high- but not low-dose IVIg therapy, as these cells showed increased FOXP3 and HLA-DR expression and enhanced suppressive capacity ex vivo, while T-helper cells were not affected (86). This finding was confirmed in a recent study showing enhanced ex vivo suppressive capacity of Tregs following IVIg treatment in GuillainBarré Syndrome patients (81). Interestingly, our study did not show an increase of circulating Tregs upon IVIg treatment (86). 
Comparison of the various human studies reveals that expansion of Treg upon IVIg therapy was only observed in patients with inflammatory diseases in which the levels of Tregs were reduced prior to IVIg infusion, while Treg did not expand in patients without Treg deficit.

Besides an increase in Treg numbers, a concomitant decrease in Th17 cells has been observed upon IVIg administration. In murine models of EAE and collagen-induced arthritis, IVIginduced expansion of Tregs while Th17 cell levels dropped (17, 87). In humans, there is similar evidence for reduction of Th17 cells after IVIg administration in Kawasaki disease (88) and Guillain Barré Syndrome patients (81). In vitro experiments suggest that IVIg inhibits cytokine-induced differentiation, amplification and function of Th17 cells from naive CD4 ${ }^{+}$T cells (89).

Collectively, expansion and enhanced suppressive activity of Tregs as well as reduction of pro-inflammatory Th17 cells seem to be common features of IVIg treatment in mice and humans. In humans high-dose IVIg therapy likely stimulates expansion of Treg only in conditions with deficit numbers of circulating Tregs before treatment. The latter observation differs from the findings in murine studies, which may be explained by the different compartments in which Treg are measured, i.e., Treg numbers in humans were determined in peripheral blood, and in mice in spleen, lymph nodes, and inflamed tissues.

Interestingly, Treg expansion and enhanced suppressive capacity may be related to induction of IL-33 production upon IVIg treatment. Three recent murine studies have shown that IL-33 directly stimulates $\mathrm{CD} 4^{+}$Foxp $3^{+}$Treg expansion (90-92). In allogeneic heart transplant models IL-33 administration resulted in expansion of recipient Tregs in cardiac grafts and spleen and in prolonged allograft survival, while depletion of Tregs from recipients eliminated any therapeutic benefit from IL-33 therapy $(90,91)$. In a chronic colitis model, administration of IL-33 induced Treg proliferation in vivo, promoted Treg accumulation in the spleen and in inflamed tissues, and prevented loss of Foxp3 expression in the inflammatory environment (92). Stimulation of Tregs by IL-33 was dependent on expression of ST2, the IL-33 receptor, on Tregs $(90,92)$. In vitro experiments showed that IL33 can serve as a cofactor in TGF- $\beta$-mediated Treg differentiation (92). However, there are no data yet to support a role of IL-33 in stimulation of Tregs by IVIg in humans.

Several other mechanisms by which IVIg may modulate Treg function and expansion have been postulated, and these have been extensively reviewed elsewhere (Figure 3) $(6,93,94)$. The contribution of IgG sialylation on Treg expansion has been recently addressed in several studies. As mentioned, in a murine model of antigen-driven allergic airway disease induction of antigenspecific Treg differentiation was dependent on binding of sIVIg to DCIR on DCs (62). In contrast, in HSE and EAE mouse models IgG sialylation was not required for functional activation of Tregs $(22,24)$. IVIg-induced expansion of human Tregs by moDCs in vitro was partially mediated by DC-SIGN in a
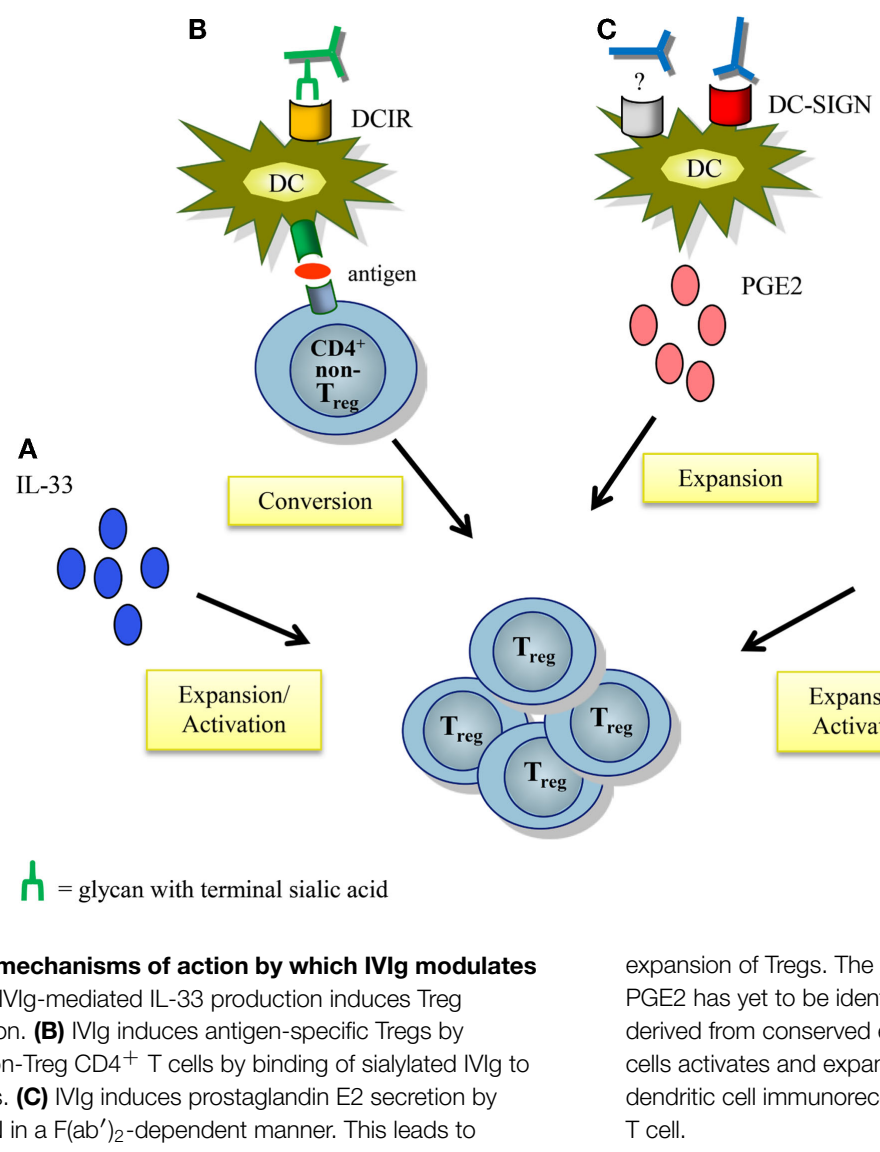

D



regulatory T cells. (A) IVIg-mediated IL-33 production induces Treg proliferation and activation. (B) IVIg induces antigen-specific Tregs by tolerogenic DCs from non-Treg CD4 ${ }^{+} \mathrm{T}$ cells by binding of sialylated IVlg to DCIR expressed on DCs. (C) IVlg induces prostaglandin E2 secretion by DCs, partly via DC-SIGN in a $F\left(a b^{\prime}\right)_{2}$-dependent manner. This leads to

expansion of Tregs. The other "IVlg-receptor" involved in the secretion of PGE2 has yet to be identified. (D) Presentation of Treg-activating peptides derived from conserved epitopes of IgG (Tregitopes) by antigen-presenting cells activates and expands Tregs. APC, antigen-presenting cell; DCIR, dendritic cell immunoreceptor; PGE2, prostaglandin E2; Treg, regulatory T cell. 
TABLE 1 | Summary of studies on the anti-inflammatory activities of IVIg in mice and humans.

\begin{tabular}{|c|c|c|c|c|}
\hline \multirow[b]{2}{*}{$\begin{array}{l}\text { Anti-inflammatory activity } \\
\text { of IVIG related to }\end{array}$} & \multicolumn{2}{|l|}{ Mice } & \multicolumn{2}{|c|}{ Humans } \\
\hline & Confirming evidence & Opposing evidence & Confirming evidence & Opposing evidence \\
\hline \multicolumn{5}{|l|}{ Fc $\gamma R I I B / F c \gamma R I I b$} \\
\hline Functional role & $\begin{array}{l}\operatorname{ITP}(8,38) \\
\operatorname{K} / B \times N \text { arthritis }(9,10,13,14) \\
\text { EBA (14) } \\
\operatorname{HSE}(24)\end{array}$ & $\begin{array}{l}\operatorname{ITP}(15,16) \\
\operatorname{EAE}(17)\end{array}$ & None & None \\
\hline Enhanced expression & $\begin{array}{l}\text { ITP (8) } \\
\text { K/BxN arthritis (9) } \\
\text { HSE (24) }\end{array}$ & None & HD: CIDP (32) & 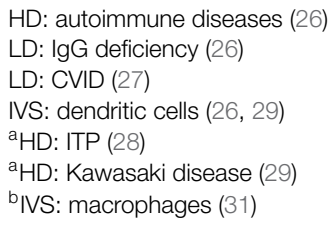 \\
\hline \multicolumn{5}{|l|}{ IL-33 } \\
\hline Functional role & K/BxN arthritis (13) & ITP (21) & None & None \\
\hline Enhanced expression & K/BxN arthritis (13) & None & $\begin{array}{l}\text { HD: autoimmune diseases (26) } \\
\text { LD: IgG deficiency (26) } \\
\text { HD: rheumatic arthritis (36) } \\
\text { IVS: macrophages (26) }\end{array}$ & None \\
\hline \multicolumn{5}{|l|}{ IL-4 and IL-13 } \\
\hline Functional role & K/BxN arthritis (13) & ITP (21) & None & None \\
\hline Enhanced expression & K/BxN arthritis (13) & None & $\begin{array}{l}\text { HD: autoimmune diseases (26) } \\
\text { LD: IgG deficiency (26) }\end{array}$ & HD: rheumatoid arthritis (36) \\
\hline \multicolumn{5}{|l|}{ Basophils } \\
\hline Functional role & K/BxN arthritis (13) & $\begin{array}{l}\text { K/BxN arthritis (23) } \\
\text { CAI arthritis (23) } \\
\text { ITP (21) }\end{array}$ & None & None \\
\hline Expansion & K/BxN arthritis (13) & None & None & HD: rheumatoid arthritis (36) \\
\hline IgG Fc & $\begin{array}{l}\text { ITP (8) } \\
\text { K/BxN arthritis }(9-13,23) \\
\text { CAI arthritis }(23)\end{array}$ & EAE (17) & $\operatorname{ITP}(65,66)$ & $\begin{array}{l}\text { IVS: dendritic cells (51) } \\
\text { IVS: monocytes (64) }\end{array}$ \\
\hline Sialylation & $\begin{array}{l}\text { ITP }(14,21,25) \\
\text { K/BxN arthritis }(10-14,25) \\
\text { CAI arthritis }(25) \\
\text { EBA }(14,25) \\
\text { Allergic airway disease (62) }\end{array}$ & $\begin{array}{l}\operatorname{ITP}(19,20) \\
\mathrm{K} / \mathrm{BxN} \text { arthritis (23) } \\
\mathrm{CAI} \text { arthritis (23) } \\
\text { EAE (22) } \\
\operatorname{HSE}(24)\end{array}$ & IVS: B cells (63) & None \\
\hline \multicolumn{5}{|l|}{ IVIg-binding proteins } \\
\hline SIGN-R1/DC-SIGN & $\begin{array}{l}\text { ITP (21) } \\
\text { K/BxN arthritis }(10,13,14) \\
\text { EBA (14) }\end{array}$ & ITP (14) & IVS: dendritic cells (51) & $\begin{array}{l}\text { IVS: macrophages }(26) \\
\text { IVS: dendritic cells }(36) \\
\text { IVS: splenocytes }(26,36)\end{array}$ \\
\hline CD22 & None & $\begin{array}{l}{ }^{\mathrm{c}} \text { ITP (69) } \\
{ }^{\mathrm{c}} \mathrm{K} / \mathrm{B} \times \mathrm{N} \text { arthritis (69) }\end{array}$ & IVS: B cells (63) & None \\
\hline $\mathrm{DCIR}$ & Allergic airway disease (62) & None & None & None \\
\hline \multicolumn{5}{|l|}{ Regulatory $\mathrm{T}$ cells } \\
\hline Expansion & $\begin{array}{l}\text { ITP (72) } \\
\text { EAE }(17,22,73) \\
\text { Allergic airway disease }(62,74,75) \\
\text { Parkinson's disease }(76) \\
\text { HSE (24) } \\
\text { CAl arthritis (87) }\end{array}$ & None & $\begin{array}{l}\text { HD: Kawasaki disease }(78,79) \\
\text { HD: Guillain Barré }(80,81) \\
\text { HD: rheumatoid arthritis }(82) \\
\text { HD: eosinophilic granulomatosis }(83) \\
\text { IVS }(51,89)\end{array}$ & $\begin{array}{l}\text { HD: autoimmune diseases (86) } \\
\text { LD: IgG deficiency (86) } \\
\text { LD: CVID (84) }\end{array}$ \\
\hline Enhanced suppressive capacity & $\begin{array}{l}\text { EAE (73) } \\
\text { Allergic airway disease (75) } \\
\text { Skin-allograft (77) }\end{array}$ & None & $\begin{array}{l}\text { HD: autoimmune diseases (86) } \\
\text { HD: Guillain Barré (81) }\end{array}$ & None \\
\hline
\end{tabular}

$H D$, high dose IVIg; LD, low-dose IVIg; IVS, in vitro studies on human immune cells; ITP, immune thrombocytopenic purpura model; EBA, autoimmune skin-blistering epidermolysis bullosa acquisita pemphigus model; K/BXN arthritis, KJBXN serum-induced arthritis model; CAl arthritis, collagen-antibody-induced arthritis model; EAE, experimental autoimmune encephalomyelitis model; HSE, HSV-1-induced encephalitis model; CIDP, chronic inflammatory demyelinating polyneuropathy; CVID, common variable immune deficiency.

${ }^{a}$ The antibody used in these studies is not suitable to detect the surface expression of FcyRllb.

${ }^{b} \mathrm{NIg}$ concentration used in this study was at least 100-fold lower than the anti-inflammatory IVIg concentration of $10 \mathrm{mg} / \mathrm{ml}$.

${ }^{\mathrm{C}} \mathrm{CD} 22^{-1-}$ mice are not suitable to determine whether the anti-inflammatory activity of IVIg is mediated via human CD22 (see Alternative IVIg-Sensing Molecules). 
$\mathrm{F}\left(\mathrm{ab}^{\prime}\right)_{2}$-dependent manner, but it is unknown whether IgG sialylation was involved (51). In addition, expansion and activation of Tregs upon recognition of specific IgG-derived peptides, called Tregitopes, that are presented by antigen-presenting cells, is sialylation-independent $(95,96)$. Collectively, sialylation is probably not required for the anti-inflammatory activity of IVIg via Tregs, but further study, especially in human settings, is warranted to unequivocally determine the contribution of IgG sialylation and the IL-33-Th2 cytokine cascade on IVIg-driven Treg expansion and function, both in antibody-mediated inflammatory diseases as well as in T-cell-mediated autoimmune pathologies.

\section{Toward Studying the Cellular and Molecular Pathways Required for IVIg-Mediated Immunosuppression in Humans}

In Table 1, we have summarized the studies which we discussed above on the anti-inflammatory activity of IVIg in mice and humans. Despite the vast knowledge that has been gained on the anti-inflammatory activity of IVIg in mice, it is surprising how little we know of its immunosuppressive mechanisms-of-action in humans. The IL-33-Th2 cytokine cascade identified in mice is also activated in humans treated with IVIg, and results in reduced sensitivity of DCs to activation by ICs and IFN- $\gamma$, but there are significant differences in the cellular and molecular components of this pathway between mice and men. Most evidence shows no upregulation of inhibitory Fc $\gamma$ RIIb, but instead downregulation of Fc $\gamma$ RIIa expression on myeloid cells after IVIg-therapy in humans. Moreover, the hypothesis that Fc-sialylation is absolutely required for the anti-inflammatory effects of IVIg in mice has become controversial, and virtually no data supporting translation of this hypothesis to humans are available. In contrast, induction of Treg expansion and suppressive capacity by IVIg seems a common anti-inflammatory pathway exploited by IVIg in mice and men. However, the molecular mechanisms used by IVIg to initiate this anti-inflammatory cascades in humans are unresolved. Priority should therefore be given to investigate whether IgG glycoforms are critical components of anti-inflammatory activity of IVIg

\section{References}

1. Gelfand EW. Intravenous immune globulin in autoimmune and inflammatory diseases. N Engl J Med (2012) 367(21):2015-25. doi:10.1056/ NEJMra1009433

2. Imbach P, Dapuzzo V, Hirt A, Rossi E, Vest M, Barandun S, et al. Highdose intravenous gamma-globulin for idiopathic thrombocytopenic purpura in childhood. Lancet (1981) 1(8232):1228-31. doi:10.1016/S0140-6736(81) 92400-4

3. Tha-In T, Bayry J, Metselaar HJ, Kaveri SV, Kwekkeboom J. Modulation of the cellular immune system by intravenous immunoglobulin. Trends Immunol (2008) 29(12):608-15. doi:10.1016/j.it.2008.08.004

4. Schwab I, Nimmerjahn F. Intravenous immunoglobulin therapy: how does IgG modulate the immune system? Nat Rev Immunol (2013) 13(3):176-89. doi:10.1038/nri3401

5. Ballow M. The IgG molecule as a biological immune response modifier: mechanisms of action of intravenous immune serum globulin in autoimmune and inflammatory disorders. J Allergy Clin Immunol (2011) 127(2):315-23. doi:10. 1016/j.jaci.2010.10.030 in humans. In addition, efforts to identify human IVIg-sensing molecules on human cells are warranted.

Although we value the mechanistic insights that have been gained on the working mechanisms of IVIg in mice, we recommend, in light of the biological differences between mice and men, studying the immunomodulatory pathways of IVIg in humans using ex vivo measurements, as well as in vitro studies on human cells. We advocate for the initiation of large, multicenter trials on patients with various indications to most effectively answer how IVIg modulates the immune system in humans in vivo at a cellular and molecular level, ideally with system biology approaches. Only then can we truly dissect which anti-inflammatory mechanisms are activated by IVIg and which components within IVIg are essential to gain potent anti-inflammatory responses that are disease- or risk group-specific. Alternatively, to address causality, studies should be initiated using immunodeficient mice reconstituted with a human immune system, although it is unclear whether current humanized mice disease models are adequate enough to mimic what occurs upon IVIg treatment in humans (97). In the light of the growing demand for IVIg, concomitant with the predicted shortage of human plasma in the future and the high costs of IVIg therapy, it is of utmost importance to unravel the molecular interactions between IVIg and the human immune system, as such knowledge may enable the design of biologicals or small molecule drugs that mimic the anti-inflammatory effects of IVIg.

\section{Author Contributions}

All the authors were involved in designing, drafting and revising the manuscript. In addition, the authors have all given final approval for the manuscript to be published, and agree to its accuracy and integrity.

\section{Acknowledgments}

This work was supported by a Mosaic grant of the Netherlands Organization for Scientific Research (NWO 017.007.055 to AT) and an unrestricted grant from Biotest Pharma (Dreieich, Germany to JK).

6. Kwekkeboom J. Modulation of dendritic cells and regulatory T cells by naturally occurring antibodies. Adv Exp Med Biol (2012) 750:133-44. doi:10.1007/ 978-1-4614-3461-0_10

7. Seite JF, Hillion S, Harbonnier T, Pers JO. Intravenous immunoglobulin and B cells when the product regulates the producer. Arthritis Rheumatol (2014) 67(3):595-603. doi:10.1002/art.38910

8. Samuelsson A, Towers TL, Ravetch JV. Anti-inflammatory activity of IVIG mediated through the inhibitory Fc receptor. Science (2001) 291(5503):484-6. doi:10.1126/science.291.5503.484

9. Bruhns P, Samuelsson A, Pollard JW, Ravetch JV. Colony-stimulating factor1-dependent macrophages are responsible for IVIG protection in antibodyinduced autoimmune disease. Immunity (2003) 18(4):573-81. doi:10.1016/ S1074-7613(03)00080-3

10. Anthony RM, Wermeling F, Karlsson MCI, Ravetch JV. Identification of a receptor required for the anti-inflammatory activity of IVIG. Proc Natl Acad Sci U S A (2008) 105(50):19571-8. doi:10.1073/pnas.0810163105

11. Kaneko Y, Nimmerjahn F, Ravetch EV. Anti-inflammatory activity of immunoglobulin G resulting from Fc sialylation. Science (2006) 313(5787):670-3. doi:10.1126/science.1129594 
12. Anthony RM, Nimmerjahn F, Ashline DJ, Reinhold VN, Paulson JC, Ravetch JV. Recapitulation of IVIG anti-inflammatory activity with a recombinant IgG fc. Science (2008) 320(5874):373-6. doi:10.1126/science.1154315

13. Anthony RM, Kobayashi T, Wermeling F, Ravetch JV. Intravenous gammaglobulin suppresses inflammation through a novel T(H)2 pathway. Nature (2011) 475(7354):110-U33. doi:10.1038/nature10134

14. Schwab I, Mihai S, Seeling M, Kasperkiewicz M, Ludwig RJ, Nimmerjahn F. Broad requirement for terminal sialic acid residues and FcgammaRIIB for the preventive and therapeutic activity of intravenous immunoglobulins in vivo. Eur J Immunol (2014) 44(5):1444-53. doi:10.1002/eji.201344230

15. Leontyev D, Katsman Y, Branch DR. Mouse background and IVIG dosage are critical in establishing the role of inhibitory Fc gamma receptor for the amelioration of experimental ITP. Blood (2012) 119(22):5261-4. doi:10.1182/ blood-2012-03-415695

16. Bazin R, Lemieux R, Tremblay T. Reversal of immune thrombocytopenia in mice by cross-linking human immunoglobulin $\mathrm{G}$ with a high-affinity monoclonal antibody. Br J Haematol (2006) 135(1):97-100. doi:10.1111/j.1365-2141. 2006.06245.x

17. Othy S, Hegde P, Topcu S, Sharma M, Maddur MS, Lacroix-Desmazes S, et al. Intravenous gammaglobulin inhibits encephalitogenic potential of pathogenic T cells and interferes with their trafficking to the central nervous system, implicating sphingosine-1 phosphate receptor 1-mammalian target of rapamycin axis. J Immunol (2013) 190(9):4535-41. doi:10.4049/jimmunol.1201965

18. von Gunten S, Shoenfeld Y, Blank M, Branch DR, Vassilev T, Kasermann F, et al. IVIG pluripotency and the concept of Fc-sialylation: challenges to the scientist. Nat Rev Immunol (2014) 14(5):349. doi:10.1038/nri3401-c1

19. Leontyev D, Katsman Y, Ma XZ, Miescher S, Kasermann F, Branch DR. Sialylation-independent mechanism involved in the amelioration of murine immune thrombocytopenia using intravenous gammaglobulin. Transfusion (2012) 52(8):1799-805. doi:10.1111/j.1537-2995.2011.03517.x

20. Guhr T, Bloem J, Derksen NI, Wuhrer M, Koenderman AH, Aalberse RC, et al. Enrichment of sialylated IgG by lectin fractionation does not enhance the efficacy of immunoglobulin $\mathrm{G}$ in a murine model of immune thrombocytopenia. PLoS One (2011) 6(6):e21246. doi:10.1371/journal.pone.0021246

21. Schwab I, Biburger M, Kronke G, Schett G, Nimmerjahn F. IVIg-mediated amelioration of ITP in mice is dependent on sialic acid and SIGNR1. Eur J Immunol (2012) 42(4):826-30. doi:10.1002/eji.201142260

22. Othy S, Topcu S, Saha C, Kothapalli P, Lacroix-Desmazes S, Kasermann F, et al. Sialylation may be dispensable for reciprocal modulation of helper $\mathrm{T}$ cells by intravenous immunoglobulin. Eur J Immunol (2014) 44(7):2059-63. doi:10.1002/eji.201444440

23. Campbell IK, Miescher S, Branch DR, Mott PJ, Lazarus AH, Han D, et al. Therapeutic effect of IVIG on inflammatory arthritis in mice is dependent on the Fc portion and independent of sialylation or basophils. J Immunol (2014) 192(11):5031-8. doi:10.4049/jimmunol.1301611

24. Ramakrishna C, Newo AN, Shen YW, Cantin E. Passively administered pooled human immunoglobulins exert IL-10 dependent anti-inflammatory effects that protect against fatal HSV encephalitis. PLoS Pathog (2011) 7(6):e1002071. doi:10.1371/journal.ppat.1002071

25. Washburn N, Schwab I, Ortiz D, Bhatnagar N, Lansing JC, Medeiros A, et al. Controlled tetra-Fc sialylation of IVIg results in a drug candidate with consistent enhanced anti-inflammatory activity. Proc Natl Acad Sci U S A (2015) 112(11):E1297-306. doi:10.1073/pnas.1422481112

26. Tjon AS, van Gent R, Jaadar H, Martin van Hagen P, Mancham S, van der Laan LJ, et al. Intravenous immunoglobulin treatment in humans suppresses dendritic cell function via stimulation of IL-4 and IL-13 production. J Immunol (2014) 192(12):5625-34. doi:10.4049/jimmunol.1301260

27. Siedlar M, Strach M, Bukowska-Strakova K, Lenart M, Szaflarska A, Weglarczyk $\mathrm{K}$, et al. Preparations of intravenous immunoglobulins diminish the number and proinflammatory response of CD14+CD16++ monocytes in common variable immunodeficiency (CVID) patients. Clin Immunol (2011) 139(2):122-32. doi:10.1016/j.clim.2011.01.002

28. Shimomura M, Hasegawa S, Seki Y, Fukano R, Hotta N, Ichiyama T. Intravenous immunoglobulin does not increase FcgammaRIIB expression levels on monocytes in children with immune thrombocytopenia. Clin Exp Immunol (2012) 169(1):33-7. doi:10.1111/j.1365-2249.2012.04591.x

29. Ichiyama T, Ueno Y, Hasegawa M, Ishikawa Y, Matsubara T, Furukawa S. Intravenous immunoglobulin does not increase FcgammaRIIB expression on monocytes/macrophages during acute Kawasaki disease. Rheumatology (Oxford) (2005) 44(3):314-7. doi:10.1093/rheumatology/keh488

30. Boruchov AM, Heller G, Veri MC, Bonvini E, Ravetch JV, Young JW. Activating and inhibitory IgG Fc receptors on human DCs mediate opposing functions. J Clin Invest (2005) 115(10):2914-23. doi:10.1172/JCI24772

31. Nagelkerke SQ, Dekkers G, Kustiawan I, van de Bovenkamp FS, Geissler J, Plomp R, et al. Inhibition of FcgammaR-mediated phagocytosis by IVIg is independent of IgG-Fc sialylation and FcgammaRIIb in human macrophages. Blood (2014) 124(25):3709-18. doi:10.1182/blood-2014-05-576835

32. Tackenberg B, Jelcic I, Baerenwaldt A, Oertel WH, Sommer N, Nimmerjahn F, et al. Impaired inhibitory Fcgamma receptor IIB expression on B cells in chronic inflammatory demyelinating polyneuropathy. Proc Natl Acad Sci U S A (2009) 106(12):4788-92. doi:10.1073/pnas.0807319106

33. Nimmerjahn F, Ravetch JV. Divergent immunoglobulin g subclass activity through selective Fc receptor binding. Science (2005) 310(5753):1510-2. doi:10. 1126/science. 1118948

34. Qiu WQ, de Bruin D, Brownstein BH, Pearse R, Ravetch JV. Organization of the human and mouse low-affinity Fc gamma R genes: duplication and recombination. Science (1990) 248(4956):732-5. doi:10.1126/science.2139735

35. Nimmerjahn F, Ravetch JV. Fcgamma receptors: old friends and new family members. Immunity (2006) 24(1):19-28. doi:10.1016/j.immuni.2005.11.010

36. Sharma M, Schoindre Y, Hegde P, Saha C, Maddur MS, Stephen-Victor E, et al. Intravenous immunoglobulin-induced IL-33 is insufficient to mediate basophil expansion in autoimmune patients. Sci Rep (2014) 4:5672. doi:10.1038/ srep05672

37. Park-Min KH, Serbina NV, Yang W, Ma X, Krystal G, Neel BG, et al. FcgammaRIII-dependent inhibition of interferon-gamma responses mediates suppressive effects of intravenous immune globulin. Immunity (2007) 26(1):67-78. doi:10.1016/j.immuni.2006.11.010

38. Siragam V, Crow AR, Brinc D, Song S, Freedman J, Lazarus AH. Intravenous immunoglobulin ameliorates ITP via activating Fc gamma receptors on dendritic cells. Nat Med (2006) 12(6):688-92. doi:10.1038/nm1416

39. Pecaric-Petkovic T, Didichenko SA, Kaempfer S, Spiegl N, Dahinden CA. Human basophils and eosinophils are the direct target leukocytes of the novel IL-1 family member IL-33. Blood (2009) 113(7):1526-34. doi:10.1182/ blood-2008-05-157818

40. Suzukawa M, Iikura M, Koketsu R, Nagase H, Tamura C, Komiya A, et al. An IL-1 cytokine member, IL-33, induces human basophil activation via its ST2 receptor. J Immunol (2008) 181(9):5981-9. doi:10.4049/jimmunol.181. 9.5981

41. Smithgall MD, Comeau MR, Yoon BR, Kaufman D, Armitage R, Smith DE. IL33 amplifies both Th1- and Th2-type responses through its activity on human basophils, allergen-reactive Th2 cells, iNKT and NK cells. Int Immunol (2008) 20(8):1019-30. doi:10.1093/intimm/dxn060

42. Geijtenbeek TBH, Groot PC, Nolte MA, van Vliet SJ, Gangaram-Panday ST, van Duijnhoven GCF, et al. Marginal zone macrophages express a murine homologue of DC-SIGN that captures blood-borne antigens in vivo. Blood (2002) 100(8):2908-16. doi:10.1182/blood-2002-04-1044

43. Steiniger B, Barth P, Herbst B, Hartnell A, Crocker PR. The species-specific structure of microanatomical compartments in the human spleen: strongly sialoadhesin-positive macrophages occur in the perifollicular zone, but not in the marginal zone. Immunology (1997) 92(2):307-16. doi:10.1046/j.1365-2567. 1997.00328.x

44. Van Krieken JH, Velde JT. Immunohistology of the human spleen - an inventory of the localization of lymphocyte subpopulations. Histopathology (1986) 10(3):285-94. doi:10.1111/j.1365-2559.1986.tb02482.x

45. Pack M, Trumpfheller C, Thomas D, Park CG, Granelli-Piperno A, Muenz C, et al. DEC-205/CD205(+) dendritic cells are abundant in the white pulp of the human spleen, including the border region between the red and white pulp. Immunology (2008) 123(3):438-46. doi:10.1111/j.1365-2567.2007.02710.x

46. Cines DB, Bussel JB. How I treat idiopathic thrombocytopenic purpura (ITP). Blood (2005) 106(7):2244-51. doi:10.1182/blood-2004-12-4598

47. Angel CE, Chen CJJ, Horlacher OC, Winkler S, John T, Browning J, et al. Distinctive localization of antigen-presenting cells in human lymph nodes. Blood (2009) 113(6):1257-67. doi:10.1182/blood-2008-06-165266

48. Granelli-Piperno A, Pritsker A, Pack M, Shimeliovich I, Arrighi JF, Park CG, et al. Dendritic cell-specific intercellular adhesion molecule 3-grabbing nonintegrin/CD209 is abundant on macrophages in the normal human lymph 
node and is not required for dendritic cell stimulation of the mixed leukocyte reaction. J Immunol (2005) 175(7):4265-73. doi:10.4049/jimmunol.175.7.4265 49. Sanada S, Hakuno D, Higgins LJ, Schreiter ER, McKenzie ANJ, Lee RT. IL-33 and ST2 comprise a critical biomechanically induced and card ioprotective signaling system. J Clin Invest (2007) 117(6):1538-49. doi:10.1172/ JCI30634

50. Willart MAM, Deswarte K, Pouliot P, Braun H, Beyaert R, Lambrecht BN, et al. Interleukin-1 alpha controls allergic sensitization to inhaled house dust mite via the epithelial release of GM-CSF and IL-33. J Exp Med (2012) 209(8):1505-17. doi:10.1084/jem.20112691

51. Trinath J, Hegde P, Sharma M, Maddur MS, Rabin M, Vallat JM, et al. Intravenous immunoglobulin expands regulatory $\mathrm{T}$ cells via induction of cyclooxygenase-2-dependent prostaglandin E2 in human dendritic cells. Blood (2013) 122(8):1419-27. doi:10.1182/blood-2012-11-468264

52. Koppel EA, van Gisbergen KPJM, Geijtenbeek TBH, van Kooyk Y. Distinct functions of DC-SIGN and its homologues L-SIGN (DC-SIGNR) and mSIGNR1 in pathogen recognition and immune regulation. Cell Microbiol (2005) 7(2):157-65. doi:10.1111/j.1462-5822.2004.00480.x

53. Bashirova AA, Geijtenbeek TBH, van Duijnhoven GCF, van Vliet SJ, Eilering JBG, Martin MP, et al. A dendritic cell-specific intercellular adhesion molecule 3 -grabbing nonintegrin (DC-SIGN)-related protein is highly expressed on human liver sinusoidal endothelial cells and promotes HIV-1 infection. J Exp Med (2001) 193(6):671-8. doi:10.1084/jem.193.6.671

54. Pohlmann S, Soilleux EJ, Baribaud F, Leslie GJ, Morris LS, Trowsdale J, et al. DC-SIGNR, a DC-SIGN homologue expressed in endothelial cells, binds to human and simian immunodeficiency viruses and activates infection in trans. Proc Natl Acad Sci U S A (2001) 98(5):2670-5. doi:10.1073/pnas.051631398

55. Frison N, Taylor ME, Soilleux E, Bousser MT, Mayer R, Monsigny M, et al. Oligolysine-based oligosaccharide clusters - Selective recognition and endocytosis by the mannose receptor and dendritic cell-specific intercellular adhesion molecule 3 (ICAM-3)-grabbing nonintegrin. J Biol Chem (2003) 278(26):23922-9. doi:10.1074/jbc.M302483200

56. Feinberg H, Mitchell DA, Drickamer K, Weis WI. Structural basis for selective recognition of oligosaccharides by DC-SIGN and DC-SIGNR. Science (2001) 294(5549):2163-6. doi:10.1126/science.1066371

57. Guo Y, Feinberg H, Conroy E, Mitchell DA, Alvarez R, Blixt O, et al. Structural basis for distinct ligand-binding and targeting properties of the receptors DCSIGN and DC-SIGNR. Nat Struct Mol Biol (2004) 11(7):591-8. doi:10.1038/ nsmb784

58. Sondermann P, Pincetic A, Maamary J, Lammens K, Ravetch JV. General mechanism for modulating immunoglobulin effector function. Proc Natl Acad Sci U S A (2013) 110(24):9868-72. doi:10.1073/pnas.1307864110

59. Crispin M, Yu XJ, Bowden TA. Crystal structure of sialylated IgG Fc: implications for the mechanism of intravenous immunoglobulin therapy. Proc Natl Acad Sci U S A (2013) 110(38):E3544-6. doi:10.1073/pnas.1310657110

60. Sondermann P, Pincetic A, Maamary J, Lammens K, Ravetch JV. Reply to Crispin et al.: molecular model that accounts for the biological and physical properties of sialylated Fc. Proc Natl Acad Sci U S A (2013) 110(38):E3547-E. doi:10.1073/pnas.1311721110

61. Yu XJ, Vasiljevic S, Mitchell DA, Crispin M, Scanlan CN. Dissecting the molecular mechanism of Mg therapy: the interaction between serum IgG and DCSIGN is independent of antibody glycoform or Fc domain. J Mol Biol (2013) 425(8):1253-8. doi:10.1016/j.jmb.2013.02.006

62. Massoud AH, Yona M, Xue D, Chouiali F, Alturaihi H, Ablona A, et al. Dendritic cell immunoreceptor: a novel receptor for intravenous immunoglobulin mediates induction of regulatory T cells. J Allergy Clin Immunol (2014) 133(3):853-63 e5. doi:10.1016/j.jaci.2013.09.029

63. Seite JF, Cornec D, Renaudineau Y, Youinou P, Mageed RA, Hillion S. IVIg modulates BCR signaling through CD22 and promotes apoptosis in mature human B lymphocytes. Blood (2010) 116(10):1698-704. doi:10.1182/ blood-2009-12-261461

64. Kasermann F, Boerema DJ, Ruegsegger M, Hofmann A, Wymann S, Zuercher AW, et al. Analysis and functional consequences of increased Fab-sialylation of intravenous immunoglobulin (IVIG) after lectin fractionation. PLoS One (2012) 7(6):e37243. doi:10.1371/journal.pone.0037243

65. Debre M, Bonnet MC, Fridman WH, Carosella E, Philippe N, Reinert P, et al. Infusion of $\mathrm{Fc}$ gamma fragments for treatment of children with acute immune thrombocytopenic purpura. Lancet (1993) 342(8877):945-9. doi:10. 1016/0140-6736(93)92000-J
66. Burdach SE, Evers KG, Geursen RG. Treatment of acute idiopathic thrombocytopenic purpura of childhood with intravenous immunoglobulin G: comparative efficacy of $7 \mathrm{~S}$ and $5 \mathrm{~S}$ preparations. J Pediatr (1986) 109(5):770-5. doi:10.1016/S0022-3476(86)80691-6

67. Edwards AD, Chaussabel D, Tomlinson S, Schulz O, Sher A, Sousa CRE. Relationships among murine $\mathrm{CD} 11 \mathrm{c}$ (high) dendritic cell subsets as revealed by baseline gene expression patterns. J Immunol (2003) 171(1):47-60. doi:10.4049/ jimmunol.171.1.47

68. Powell LD, Sgroi D, Sjoberg ER, Stamenkovic I, Varki A. Natural ligands of the B-cell adhesion molecule $\mathrm{Cd} 22$-beta carry $\mathrm{n}$-linked oligosaccharides with alpha-2,6-linked sialic acids that are required for recognition. J Biol Chem (1993) 268(10):7019-27.

69. Schwab I, Seeling M, Biburger M, Aschermann S, Nitschke L, Nimmerjahn F. $\mathrm{B}$ cells and CD22 are dispensable for the immediate antiinflammatory activity of intravenous immunoglobulins in vivo. Eur J Immunol (2012) 42(12):3302-9. doi:10.1002/eji.201242710

70. Varki A. Multiple changes in sialic acid biology during human evolution. Glycoconj J (2009) 26(3):231-45. doi:10.1007/s10719-008-9183-z

71. Brinkman-Van der Linden EC, Sjoberg ER, Juneja LR, Crocker PR, Varki N, Varki A. Loss of N-glycolylneuraminic acid in human evolution - Implications for sialic acid recognition by siglecs. J Biol Chem (2000) 275(12):8633-40. doi:10.1074/jbc.275.12.8633

72. Aslam R, Hu Y, Gebremeskel S, Segel GB, Speck ER, Guo L, et al Thymic retention of CD4(+)CD25(+)FoxP3(+) T regulatory cells is associated with their peripheral deficiency and thrombocytopenia in a murine model of immune thrombocytopenia. Blood (2012) 120(10):2127-32. doi:10.1182/ blood-2012-02-413526

73. Ephrem A, Chamat S, Miquel C, Fisson S, Mouthon L, Caligiuri G, et al. Expansion of $\mathrm{CD} 4+\mathrm{CD} 25+$ regulatory $\mathrm{T}$ cells by intravenous immunoglobulin: a critical factor in controlling experimental autoimmune encephalomyelitis. Blood (2008) 111(2):715-22. doi:10.1182/blood-2007-03-079947

74. Kaufman GN, Massoud AH, Audusseau S, Banville-Langelier AA, Wang Y, Guay J, et al. Intravenous immunoglobulin attenuates airway hyperresponsiveness in a murine model of allergic asthma. Clin Exp Allergy (2011) 41(5):718-28. doi:10.1111/j.1365-2222.2010.03663.x

75. Massoud AH, Guay J, Shalaby KH, Bjur E, Ablona A, Chan D, et al. Intravenous immunoglobulin attenuates airway inflammation through induction of forkhead box protein 3-positive regulatory T cells. J Allergy Clin Immunol (2012) 129(6):1656-65 e3. doi:10.1016/j.jaci.2012.02.050

76. St-Amour I, Bousquet M, Pare I, Drouin-Ouellet J, Cicchetti F, Bazin R, et al. Impact of intravenous immunoglobulin on the dopaminergic system and immune response in the acute MPTP mouse model of Parkinson's disease. $J$ Neuroinflammation (2012) 9:234. doi:10.1186/1742-2094-9-234

77. Tha-In T, Metselaar HJ, Bushell AR, Kwekkeboom J, Wood KJ. Intravenous immunoglobulins promote skin allograft acceptance by triggering functional activation of CD4+Foxp3+ T cells. Transplantation (2010) 89(12):1446-55. doi:10.1097/TP.0b013e3181dd6bf1

78. Hirabayashi Y, Takahashi Y, Xu YY, Akane K, Villalobos IB, Okuno Y, et al. Lack of $\mathrm{CD} 4(+) \mathrm{CD} 25(+) \mathrm{FOXP} 3(+)$ regulatory $\mathrm{T}$ cells is associated with resistance to intravenous immunoglobulin therapy in patients with Kawasaki disease. Eur $J$ Pediatr (2013) 172(6):833-7. doi:10.1007/s00431-013-1937-3

79. Olivito B, Taddio A, Simonini G, Massai C, Ciullini S, Gambineri E, et al. Defective FOXP3 expression in patients with acute Kawasaki disease and restoration by intravenous immunoglobulin therapy. Clin Exp Rheumatol (2010) 28(1 Suppl 57):93-7.

80. Chi LJ, Wang HB, Zhang Y, Wang WZ. Abnormality of circulating $\mathrm{CD} 4(+) \mathrm{CD} 25(+)$ regulatory $\mathrm{T}$ cell in patients with Guillain-Barre syndrome. J Neuroimmunol (2007) 192(1-2):206-14. doi:10.1016/j.jneuroim.2007.09.034

81. Maddur MS, Rabin M, Hegde P, Bolgert F, Guy M, Vallat JM, et al. Intravenous immunoglobulin exerts reciprocal regulation of Th1/Th17 cells and regulatory $\mathrm{T}$ cells in Guillain-Barre syndrome patients. Immunol Res (2014) 60(2-3):320-9. doi:10.1007/s12026-014-8580-6

82. Bayry J, Mouthon L, Kaveri SV. Intravenous immunoglobulin expands regulatory T cells in autoimmune rheumatic disease. J Rheumatol (2012) 39(2):450-1. doi:10.3899/jrheum.111123

83. Tsurikisawa N, Saito H, Oshikata C, Tsuburai T, Akiyama K. High-dose intravenous immunoglobulin treatment increases regulatory $\mathrm{T}$ cells in patients with eosinophilic granulomatosis with polyangiitis. J Rheumatol (2012) 39(5):1019-25. doi:10.3899/jrheum.110981 
84. Paquin-Proulx D, Santos BA, Carvalho KI, Toledo-Barros M, Barreto de Oliveira AK, Kokron CM, et al. IVIg immune reconstitution treatment alleviates the state of persistent immune activation and suppressed CD4 T cell counts in CVID. PLoS One (2013) 8(10):e75199. doi:10.1371/journal.pone.0075199

85. Melo KM, Carvalho KI, Bruno FR, Ndhlovu LC, Ballan WM, Nixon DF, et al. A decreased frequency of regulatory $\mathrm{T}$ cells in patients with common variable immunodeficiency. PLoS One (2009) 4(7):e6269. doi:10.1371/journal. pone. 0006269

86. Tjon AS, Tha-In T, Metselaar HJ, van Gent R, van der Laan LJ, Groothuismink ZM, et al. Patients treated with high-dose intravenous immunoglobulin show selective activation of regulatory T cells. Clin Exp Immunol (2013) 173(2):259-67. doi:10.1111/cei.12102

87. Lee SY, Jung YO, Ryu JG, Kang CM, Kim EK, Son HJ, et al. Intravenous immunoglobulin attenuates experimental autoimmune arthritis by inducing reciprocal regulation of Th17 and Treg cells in an interleukin-10-dependent manner. Arthritis Rheumatol (2014) 66(7):1768-78. doi:10.1002/art.38627

88. Rasouli M, Heidari B, Kalani M. Downregulation of Th17 cells and the related cytokines with treatment in Kawasaki disease. Immunol Lett (2014) 162(1 Pt A):269-75. doi:10.1016/j.imlet.2014.09.017

89. Maddur MS, Vani J, Hegde P, Lacroix-Desmazes S, Kaveri SV, Bayry J. Inhibition of differentiation, amplification, and function of human TH17 cells by intravenous immunoglobulin. J Allergy Clin Immunol (2011) 127(3): 823-30 e1-7. doi:10.1016/j.jaci.2010.12.1102

90. Turnquist HR, Zhao Z, Rosborough BR, Liu Q, Castellaneta A, Isse K, et al. IL-33 expands suppressive CD11b+ Gr-1(int) and regulatory T cells, including ST2L+ Foxp3+ cells, and mediates regulatory $\mathrm{T}$ cell-dependent promotion of cardiac allograft survival. J Immunol (2011) 187(9):4598-610. doi:10.4049/jimmunol. 1100519

91. Brunner SM, Schiechl G, Falk W, Schlitt HJ, Geissler EK, Fichtner-Feigl S. Interleukin-33 prolongs allograft survival during chronic cardiac rejection. Transpl Int (2011) 24(10):1027-39. doi:10.1111/j.1432-2277.2011.01306.x
92. Schiering C, Krausgruber T, Chomka A, Frohlich A, Adelmann K, Wohlfert EA, et al. The alarmin IL-33 promotes regulatory T-cell function in the intestine. Nature (2014) 513(7519):564-8. doi:10.1038/nature13577

93. Maddur MS, Othy S, Hegde P, Vani J, Lacroix-Desmazes S, Bayry J, et al. Immunomodulation by intravenous immunoglobulin: role of regulatory $\mathrm{T}$ cells. J Clin Immunol (2010) 30:S4-8. doi:10.1007/s10875-010-9394-5

94. Petta F, De Luca C, Triggiani M, Casolaro V. Fragments of truth: T-cell targets of polyclonal immunoglobulins in autoimmune diseases. Curr Opin Pharmacol (2014) 17C:1-11. doi:10.1016/j.coph.2014.05.002

95. Cousens LP, Najafian N, Mingozzi F, Elyaman W, Mazer B, Moise L, et al. In vitro and in vivo studies of IgG-derived Treg epitopes (Tregitopes): a promising new tool for tolerance induction and treatment of autoimmunity. J Clin Immunol (2013) 33(Suppl 1):S43-9. doi:10.1007/s10875-012-9762-4

96. De Groot AS, Moise L, McMurry JA, Wambre E, Van Overtvelt L, Moingeon P, et al. Activation of natural regulatory T cells by IgG Fc-derived peptide "Tregitopes”. Blood (2008) 112(8):3303-11. doi:10.1182/blood-2008-02-138073

97. Lux A, Nimmerjahn F. Of mice and men: the need for humanized mouse models to study human IgG activity in vivo. J Clin Immunol (2013) 33(Suppl 1):S4-8. doi:10.1007/s10875-012-9782-0

Conflict of Interest Statement: The authors declare that the research was conducted in the absence of any commercial or financial relationships that could be construed as a potential conflict of interest.

Copyright (c) 2015 Tjon, van Gent, Geijtenbeek and Kwekkeboom. This is an openaccess article distributed under the terms of the Creative Commons Attribution License (CC BY). The use, distribution or reproduction in other forums is permitted, provided the original author(s) or licensor are credited and that the original publication in this journal is cited, in accordance with accepted academic practice. No use, distribution or reproduction is permitted which does not comply with these terms. 